\title{
Language Maintenance and Cultural Viability in the Hainanese Community: A Case Study of the Melaka Hainanese
}

\author{
By Eileen Lee * \\ Shin Pyng Wong ${ }^{\dagger}$ \\ Lyon Laxman
}

\begin{abstract}
Among the different (Chinese) dialect groups from the southern region of China that migrated to Malaya (now Malaysia) in the 1900s, the Hainanese were one of the last migrant groups to arrive thus they comprise only about three percent of the population of the Chinese linguistic groups living in Malaysia. Unlike Cantonese and Hokkien (also southern China vernaculars) which became the lingua franca of the Chinese communities in Kuala Lumpur, Penang and Melaka respectively, Hainanese is not spoken as a major Chinese dialect in any particular city, town, or state in Malaysia although there may be a majority of Hainanese living in a geographical area. In a case study of the Hainanese community in Melaka, responses from interviews with community members confirm that the dialect is not being maintained as the main means of communication in the friendship and home domains. This paper reports that while video recordings of celebrations of cultural festivals, pastimes and Hainanese family businesses indicate a fair degree of cultural viability in the community due to the great sense of bonding (known as suukee nang) among members of the community, lack of communication in Hainanese does not bode well for the maintenance of the community language. The study concludes that while Hainanese culture (its sense of belonging and popular cuisine) is still viable, the same cannot be said for its language; in short, much of the dialect is not likely to survive for the next generation unless efforts are in place to revitalize this native language.
\end{abstract}

\section{Introduction}

The Chinese migration from Southern China to South East Asia, particularly Malaya began in the nineteenth century during the Qing dynasty.

\footnotetext{
*Associate Professor, Sunway University, Malaysia.

${ }^{\dagger}$ Lecturer, Sunway University, Malaysia.

${ }^{\dagger}$ Lecturer, Sunway University, Malaysia.
} 
Resentment towards the Qing government triggered the rebels' migration to South East Asia (Baidu Encyclopedia, 2013). The mass migration of Chinese started after the Qing government was defeated by Great Britain in the first Opium War and forced to sign the Treaty of Nanjing that granted its citizens the right to work abroad. As Great Britain needed plenty of human resources to develop Malaya, many Qing citizens, known as $k u l i$ (苦力) were imported from China to Malaya to work as mine and plantation workers. Since the use of steamships, the rate of Chinese migration to Malaya increased dramatically. Among the different Chinese dialect groups from the southern region of China that migrated to Malaya (now Malaysia) in the 1900s, the Hainanese were practically the last migrant group to arrive thus they comprise only about 3 per cent of the population of the Chinese linguistic groups living in Malaya (Federation of Hainan Association Malaysia, 2013).

The Hainanese migration to Malaya was due to five major reasons: poverty, Qing government's open door policy after signing the Treaty of Nanjing, rubber and mine developments in Malaya, civil wars and Japanese invasion (Federation of Hainan Association Malaysia, 2013). First, the Hainanese lived in Hainan Island which had been under-developed, working as farmers and fishermen. Struggling with poverty, many Hainanese were inclined to work overseas for a better life. Second, beginning the 19th century the Hainanese gradually resided in Penang and Melaka (Malacca). After the signing of Treaty of Nanjing that decreased the travel abroad restraint, the Hainanese migrated to Malaya massively. Third, blooming rubber and mine developments in Malaya and Singapore at the end of the 19th century led to the British and Dutch employment of labourers along the China coastal areas through their agencies. Thus, a good number of Hainanese migrated to Malaya to earn a living. Fourth, the China civil warfare had forced the Hainanese to flee their homeland. In 1927, the Kuo Ming Tang (国共) civil war caused instability and poverty in the Hainanese society. Datuk Seri Foo Sae Heng, president of the Federation of Hainan Association Malaysia (FHAM) said, "The Hainanese migrated here because of the war in China" (The Star, 2012). During the construction of Jun Gang (军港), the largest Far East military base in Singapore, many Hainanese were recruited as labourers and domestic helpers. When the Japanese conquered Hainan Island in 1937, another mass migration of the Hainanese ensued.

The mass migration of Chinese to Malaya imported various Chinese dialects such as Hainanese, Hokkien, Cantonese and Hakka. With little language shift to English and Mandarin, these Chinese languages had been widely spoken in Malaya for decades (Han, 2012). Assimilation hardly occurred in the Chinese migrant communities for which their identity was shaped through the maintenance of Chinese dialects. This raises the notion of Chineseness (华人性) which means the nature of being someone Chinese (Wang, 2009). In the 21st century, a large number of Chinese Malaysians preserve their concepts of Chineseness by adjusting their lifestyles to fit new environments. Many received local Chinese school education and used Mandarin as the lingua franca among myriad Chinese communities. Chinese 
dialects, on the other hand, have been spoken in the communities that share the ancestral roots and cultural origins from a specific province of China. The maintenance of Chinese dialects has stirred numerous debates since more young Chinese speak Mandarin, not their dialect (Sim, 2012; Wang, 2010). Unlike Cantonese and Hokkien (also southern China vernaculars) which became the lingua franca of the Chinese communities in Kuala Lumpur, Penang and Melaka respectively, the Hainanese dialect is not spoken as a major Chinese dialect in any particular city, town, or state in Malaysia although there may be a majority of Hainanese living in a geographical area. Besides the existence of other Chinese dialects, exposure to other languages including English and the rise of Mandarin as a unifying language among the Han (Chinese) people, dialects with small number of speakers such as the Hainanese dialect is under threat of loss and extinction. In view of this, this study aims to investigate language maintenance and cultural viability in the Melaka Hainanese community, one of the earliest Hainanese settlers in Malaya.

\section{The Hainanese Community in Malaya}

Hainanese lived in various states of Malaysia (then Malaya). The main cities of Kuala Lumpur, Melaka (Malacca), Penang and Johor Bahru housed a large Hainanese population. The Melaka Hainanese in particular, made up 24 per cent of the total Melaka Chinese population. Based on the latest population report of different Chinese linguistic groups in the states of Malaysia published by Department of Statistics Malaysia in 2001 (Sim, 2012), the Hainanese population dwindled to 141,045 , constituting 2.6 per cent of the total Chinese population in Malaysia.

Most Hainanese migrants settled in the states on the west coast of Malaya, such as Selangor, Johor, Perak and Melaka. The Hainanese settlement locality is often associated with chain migration (Han, 2012). According to Light (1983), chain migration is a phenomenon where migrants settled in the similar locality as their kinsmen who had migrated before them. Light and Bonacich (1988, p. 153) further discussed the function of chain migration in which it places "new population where population has already settled" and the migrants decide where to migrate based on kinship rather than on only economic benefits. Research showed that the Hainanese migrants' return to Hainan Island motivated their kinsmen to migrate to South East Asia. The Hainanese at Hainan Island perceived their kinsmen who returned from Malaya as role models of success. Migration myths or narratives strongly encouraged the villagers to attempt to earn their livelihood in Malaya (Xu, 2005). In addition, the new Hainanese migrants relied on their predecessors' assistance in the form of financial loans, accommodation and job recommendations. The kinship ties between laokheh (predecessors) and sinkheh (new migrants) stimulated chain migration as the former helped the latter to settle in Malaya with their prior knowledge and experiences (Han, 2005). 


\section{Occupational Specialisations of the Hainanese in Malaya and Singapore}

Most Hainanese migrants were involved in the service-oriented industry in which they were domestic servants to the British and wealthy Peranakan (local Chinese) homes, ran kopitiams (coffee shops) and worked in the hospitality industry such as hotels and laundry service. In Malaya and Singapore, the Hainanese were renowned for operating coffee and chicken rice shops. Wang (2009) explained that the culture of looking after own people (同乡照顾同乡) encouraged more Hainanese to run the coffee shop business. The new migrants acquired the skills of running a coffee shop when they lived with temporarily or worked in their relative's or friend's coffee shop while adapting to the Nanyang living conditions. Besides, the Hainanese choice of managing coffee shops is also closely related to their working experience at the Westerners' (European) homes. After acquiring western cooking techniques and diets, the Hainanese started coffee shop business which was founded on the Western dietary habits. Several reasons led to the Hainanese's venture into less desirable occupational specialisations. The Hainanese migrated to Malaya and Singapore much later than the other Chinese ethnic groups thus, most lucrative industries had already been dominated by other major dialect groups. Without any "primordial skillsets", many Hainanese migrants who were formerly farmers and fishermen became domestic servants, coffee shop operators and restaurant workers (Han, 2012, p. 37). Similar to Wang's (2009) findings, some acquired cooking skills during their job as a domestic servant and later taught these skills to other Hainanese co-workers. The Chinese bang (帮) structure also resulted in the Hainanese's occupational specialisations. According to Han (2012), the Hainanese business owners preferred to employ Hainanese workers and conduct business with the Hainanese due to the linguistic similarities. Evidence showed that the bang structure forbade any non-members from obtaining the jobs in a trade which was dominated by a specific dialect group. As such, the kinship and linguistic identities drew most Hainanese migrants to work in the same industry.

\section{Regional Lingua Franca(s) in Malaya}

A variety of Chinese dialects had been brought into Malaya since the mass migration of Chinese from the 19th to 20th century. The kinship ties, cultural identity, migration patterns and occupational preferences were some of the reasons that contributed to the usage of Chinese dialects among the Chinese linguistic groups (Sim, 2012; Wang, 2010). Hokkien, Hakka, Cantonese, Teochew and Hainanese were the major lingua francas in Malaya among the migrant communities which had originated from the southern China provinces of Fujian, Guangzhou, Chaozhou, Meixian and Hainan Island. Few Chinese migrants spoke Mandarin and English, as most identified with their kinsmen through the use of their Chinese dialects. The occupational specialisations and dialect group dominance also affected the choice of the spoken Chinese dialect in the areas. For example, the Hainanese employees of coffee shops spoke the Hainanese dialect to establish rapport and culture at work; the Hokkien migrant group constituted the largest Penang Chinese population and controlled the 
town's economy, thus influencing other minority migrant groups into using the Hokkien dialect as a daily communication tool. The usage of Chinese dialects is connected to the settlement locality of the migrants. Hakka had been a dominant dialect among the Chinese migrants in Kuala Lumpur when a powerful Hakka kapitan (Chinese captain), Yap Ah Loy, governed the Chinese migrant community in the mining and trade industries from the 1870s to the 1880s (Wang, 2010). After the death of the last kapitan Yap Kwan Seng, of Hakka descent, the colonial government abolished the kapitan system in 1902 (The Star, 2007). Subsequently, the Hakka political and economic influences decreased whereas the Cantonese group began to dominate the industries in the city. The Cantonese dialect eventually became the lingua franca among different Chinese migrant groups in Kuala Lumpur from 1910s till today (Wang, 2010). Likewise, in Kampung Hailam of Melaka (the Hainanese village of Malacca), nearly 95 per cent of the residents are Hainanese who speak the Hainanese dialect and practise the Hainanese traditions (Chooi, 2012; The Star, 2011).

\section{The Hainanese Dialect, Culture and Values}

The emphasis on language and cultural inheritance was evident in the Hainanese migrants in Malaya. The ability to communicate in the Hainanese dialect formed an integral part of the Hainanese identity. In the 21st century, the Hainanese dialect has been widely spoken in Hainan Island despite the usage of Mandarin as a common language (Fu, 2008). The reason is the usage of the Hainanese dialect strengthens the kinship ties among the Hainanese. The Hainanese dialect is a variant of the Southern Min language (闽南), which is used mainly in Hainan Island in the provinces of Wen Chang, Qiong Hai, Wan Ning, Ding An, Hai Kou, Qiong Shan, Cheng Mai and Tun Chang. Nevertheless, with societal changes, less of the younger generation of Hainanese can speak the Hainanese dialect. This poses risks to the maintenance of the Hainanese language in the community.

While Hainanese identity is often associated with speaking the dialect, Hainanese culture and values are often related to strong kinship ties between members of the community and the responsibility of each member of the community assisting another Hainanese. This strong bond of 'looking after one's own people' (同乡照顾同乡) as mentioned by Wang (2009) is termed as suukee nang to the Hainanese people. Literally suukee nang means 'neighbour' but within the Hainanese community the term refers to 'of one's own kind' hence the need to extend assistance and kindness. The strong sense of suukee nang is a distinctive Hainanese trait especially among senior members of the community which is highly valued by the community. This strong sense of fraternity is what keeps the community united and cohesive. In worship, another cultural value of the community is the practice of ancestor worship and the adoration of the Goddess $M a C h u$ while Hainanese cuisine such as the famous Hainanese Chicken Rice and Hainanese coffee and toast is another distinctive feature of Hainanese cooking and culture. 


\section{The Hainanese in Melaka}

\section{The Hainanese Village of Melaka (Kampong Hailam)}

Located in Tanjung Kling about 11 kilometres from the city centre, the 9 acre Hainanese Village of Melaka symbolises the Melaka Hainanese heritage and the ancestors' strengths of establishing the Melaka Hainanese settlement. Of the 50 households in the Hainanese Village of Melaka, 95 per cent of the residents are Hainanese. As the young Hainanese earn a living in the city, most villagers are the elderly who lead "a typically laid-back lifestyle in a strongly bonded society" (Guang Ming Daily, 2012), having grown accustomed to the peaceful village life by the sea. Over more than a hundred years, the Hainanese Village of Melaka has not been legitimated by the local government (Liang \& $\mathrm{Xu}, 2001)$. The two main reasons are (1) the area of the Hainanese Village is extremely small, comprising 9 acres only and (2) the land does not belong to the villagers and their attempts of obtaining land ownership failed despite the assistance of local political leaders. Now the Hainanese Village of Melaka is facing the demolition crisis. On $26^{\text {th }}$ April 2013, the 50 Hainanese households in the village received an official expropriation letter from the MHSB developer that says it owns this land (PN260, LOT28) and demanded the demolition of the houses within a month (Sin Chew Jit Poh, 2013). The letter did not mention any compensation for the demolition expenses, leaving the elderly villagers in despair. A 78-year-old villager said that he cannot demolish his home in which he grew up, received education, got married, had children and strove for a living since his migration from Hainan Island to the Village when he was three years old. Another 74-year-old villager also stressed that he does not want to leave the village and hopes to continue to live there. As the demolition crisis lingers and the urbanisation accelerates, the Hainanese Village of Melaka is likely to disappear in the near future.

\section{The Melaka Hainanese Association}

The Hainanese association represents the strong kinship ties among the Hainanese migrants. Established in 1869, the Melaka Hainanese Association (Persatuan Hainan Melaka) was the first Hainanese association in Malaya. For many years, it had the highest number of members among all the Hainanese associations (Xu, 2005). During the Japanese invasion, it was occupied and renamed as "Chinese Liason Centre". After the surrender of the Japanese in August 1945, the Melaka Hainanese Association reopened and set up its first post-war committee. Past achievements included the welfare, sports, arts, education, music, women, leisure and drama committees (The Melaka Hainanese Association Millennium Year Issue 1869-2001, 2001). Its current address is 115 Jalan Hang Jebat 75200 Melaka, Malaysia.

\section{Melaka Hainanese Cuisine}

Throughout Malaysia, each ethic group has its own distinctive cuisine. Throughout Malaysia the Hainanese are well known for the Hainanese chicken rice, coffee and toast. For the Melaka Hainanese, they are specifically known 
for their Hainanese chicken rice balls and Hainanese satay (skewered pork kebabs and intestines served with pineapple and peanut sauce).

\section{Language Maintenance and Cultural Viability of Minority Communities}

To prevent the loss of a language to another language, members of the community has to maintain the use of the language. This process of consciously maintaining the use of the language can include 'maintaining the users' proficiency in the language' (Fase et al., 1992). For the purpose of this study, language maintenance refers to continued use of the minority language, in this case the continuing use of Hainanese among members of the Melaka Hainanese community. Besides language, the maintenance of cultural practices is another challenge in this globalised world. In this study, cultural viability refers to the possibility of maintaining core cultural practices and values in the community.

\section{Language Maintenance in the Private Domains of Friends and Family}

Fishman (1972) recommends the use of domains in analysing language use and the phenomenon of language maintenance and shift. While there is no limit to the number of domains in a study, some domains like the home domain is often used in the study of language maintenance and/or shift. Unlike the other domains e.g. the school, church or work domains which are associated with 'status' values, family and friends domains are related to values of intimacy and solidarity with the vernacular or the mother tongue (Landry \& Allard, 1994); also, it is in the family and community that a peculiar bond with language and language activities (e.g. stories, conversations, verbal play) is fostered, shared and fashioned into personal and social identity (Fishman, 1990). In most ethnic communities, the ethnic language is used in family interactions, thus to detect whether a community language is maintained, most studies focus on observing language use behaviour in the family domain especially across generations of family members. If communication between family members across generations are not or cannot be successfully carried out in the ancestral language in the home domain, the chances of the ethnic language surviving in other domains is much less. Generally, the fewer domains the community language is used in, the less likely the language will be maintained and consequently, the greater the likelihood that the community language is lost.

\section{The Study}

\section{Aim \& Hypothesis}

The study examined whether there is language maintenance and cultural viability in the Hainanese community in Melaka, West Malaysia. Language maintenance is said to be taking place if members of the community use 
Hainanese as the main language of communication among friends and family and consider it vital for the dialect to be transmitted inter-generationally. There is cultural viability in the community if Hainanese cultural values and practices are still upheld in the community (and forms part of the Hainanese identity).

\section{Methodology}

Due to personal contacts and accessibility to informants, a case study was conducted on the Melaka Hainanese community. The main research tools used to collect data in this project were interviews, video documentation and participant observations. Interviews were conducted to elicit information on whether Hainanese is used as the main language of communication among family and friends as well as whether it is considered vital to transmit the Hainanese dialect to the younger generation in the home domain; video recordings of cultural festivities, pastimes and family businesses were documented and used to support observations on whether there is a sense of bonding among members of the community and whether the Hainanese cultural values and practices are still upheld in the community today.

\section{Participants and Data Collection}

In total, twenty six members of the Melaka Hainanese community participated in the study: 12 members from Generation Baby Boomers (50 years old and above) were interviewed from November 2011 to January 2012; 7 members from Generation X (30 - 49 years old) were interviewed from December 2011 - February 2012; 7 members from Generation Y (11 - 29 years old) were interviewed in May - April 2012. The following video documentations of cultural festivities, pastimes, and family businesses were recorded between December 2012 to February 2012:

a) Chinese New Year celebrations at the Melaka Hainanese Association;

b) the adoration and celebration of Goddess Ma Chu's birthday at the Melaka Hainanese Association;

c) the Kut Pai card game at Kampong Hailam;

d) Hainanese coffeeshop business at the Big Tree at Trankerah Road;

e) Hainanese satay business at Kota Laksamana;

f) Hainanese chicken rice business at Kampong Lapan.

Most of the interviews were conducted by the principal investigator while the video recordings of the cultural events and practices were carried out by the co-researcher. The interviews were transcribed by Hainanese-speaking field research assistants and the data were analysed accordingly. 


\section{Results \& Discussion}

\section{Language Maintenance in the Melaka Hainanese Community}

Table 1. Views on Language Maintenance from the Three Generations

\begin{tabular}{|c|c|c|c|}
\hline $\begin{array}{c}\text { Generation Baby Boomers ( } \geq \\
50 \text { years old) }\end{array}$ & Age & $\begin{array}{l}\text { Use Hainanese } \\
\text { with family and } \\
\text { friends? Y/N }\end{array}$ & $\begin{array}{l}\text { Vital for Hainanese to } \\
\text { be used in the home } \\
\text { (domain)? Y/N }\end{array}$ \\
\hline GBK & 76 & Yes & Yes, but sometimes not \\
\hline OSC & & & practical; \\
\hline PK & & Sometimes & It depends on who's \\
\hline KBT & 75 & & speaking it; \\
\hline AP & & & In theory yes but in \\
\hline GLY & 76 & & practice not so easy; \\
\hline $\mathrm{CJH}$ & 86 & Not all the time & The children and \\
\hline OHM & 62 & Sometimes & grandchildren are using \\
\hline TTL & 76 & $\begin{array}{l}\text { If they can speak } \\
\text { Yes }\end{array}$ & $\begin{array}{l}\text { Mandarin or English, } \\
\text { so how possible? }\end{array}$ \\
\hline TYT & 77 & Yes & Mandarin more \\
\hline WYK & 72 & Yes & important for the \\
\hline WKN & 64 & & Chinese \\
\hline \multicolumn{4}{|l|}{$\begin{array}{l}\text { Generation } X \\
(30-49 \text { years old })\end{array}$} \\
\hline $\mathrm{DC}$ & 40 & Not all the time & $\begin{array}{l}\text { It is a small language; } \\
\text { Yes, but is it possible? }\end{array}$ \\
\hline DT & 33 & Sometimes & $\begin{array}{l}\text { Maybe } \\
\text { Maybe }\end{array}$ \\
\hline BTC & 35 & Not often & Yes, but not possible \\
\hline CCS & 38 & If possible & Chinese more \\
\hline AW & 32 & Try to & important \\
\hline GYL & 47 & No & Use Mandarin \\
\hline TLL & 36 & Seldom & \\
\hline \multicolumn{4}{|l|}{$\begin{array}{l}\text { Generation } Y \\
(11-29 \text { years })\end{array}$} \\
\hline KW & 25 & No & $\begin{array}{l}\text { Not sure if it's a good } \\
\text { idea; }\end{array}$ \\
\hline RL & 22 & Can't speak & No, I don't think so; \\
\hline DL & 18 & With Ah Kong & I can speak it, so ok. \\
\hline MM & 20 & With Ah Por & $\begin{array}{l}\text { Grandma will be } \\
\text { happy; }\end{array}$ \\
\hline TK & 12 & $\begin{array}{l}\text { Can understand } \\
\text { but can't speak }\end{array}$ & Nolah; \\
\hline WG & 13 & $\begin{array}{l}\text { Can't speak, } \\
\text { sometimes can't } \\
\text { understand too }\end{array}$ & $\begin{array}{l}\text { Boy, I'm totally lost } \\
\text { touch with my mother } \\
\text { tongue! }\end{array}$ \\
\hline JP & 11 & $\begin{array}{l}\text { We don't use the } \\
\text { language at home }\end{array}$ & No \\
\hline
\end{tabular}

Responses from the three generations (Baby Boomers, Generation X, Generation Y) are tabulated in Table 1. It is clear that while the oldest 
generation (Baby Boomers) maintain a fair amount of Hainanese for communication with family and friends, the use of Hainanese as a language of communication diminishes drastically with Generations $\mathrm{X}$ and $\mathrm{Y}$ due to their inability to speak the dialect. Interestingly, views on the importance of transmitting Hainanese in the home domain does not correlate positively with Generation Baby Boomers as the respondents doubt the pragmatics of using the dialect and even highlight the use of Mandarin and English in the home. Both Generations $\mathrm{X}$ and $\mathrm{Y}$ do not see the importance of using Hainanese as a home language since most of them are not able to speak Hainanese.

\section{Cultural Viability in the Melaka Hainanese Community}

In the two cultural festivities, the Chinese New Year lion dance participation and the adoration and celebration of Goddess $\mathrm{Ma}$ Chu's birthday at the Melaka Hainanese Association, both the older and younger members of the community participated actively in the festivities. The lion dance troupe that went around Melaka city visiting Chinese houses (including Hainanese houses) were mostly headed by Generation $\mathrm{X}$ while the lion dancers were from Generation Y. In contrast, the celebrants of Goddess Ma Chu's birthday at the clan's association were mostly from Generation Baby Boomers who went to pay homage, respect and gratitude for the successes they have received. Recordings of senior and middle-aged members of the community engaged in the kut pai game display a fair amount of Hainanese being spoken but more importantly, a strong sense of bonding among the players of the game. Interviews and participant observation of Hainanese family businesses such as the Hainanese coffee shop business at the Big Tree, the Sun May Hiong Satay House and Hainanese Chicken Rice Restaurant reveal strong kinship ties that is a trademark of the Hainanese community. All these speak for a strong communal sense indicating cultural viability in the community.

\section{Conclusion}

In this study it is shown that the use of Hainanese is declining across the three generations. Although members of the oldest generation (Baby Boomers) are proficient in the dialect, unfortunately not all of them report using Hainanese in the family and friendship domains. In the case of Generation X and $\mathrm{Y}$, none of them use Hainanese to communicate in these two domains therefore Hainanese is definitely not being maintained by these generations too. Consequently, this means that there is no language maintenance in the community. In contrast, active participation in cultural festivities such as the Chinese New Year celebrations and the birthday celebration of the Goddess $M a C h u$, comradeship and speaking in the dialect when members engage in Hainanese pastimes such as the kut pai game and strong kinship ties and feelings in the family businesses provide support for cultural viability in the community. To conclude, the Hainanese dialect is not maintained in the community but there is cultural viability in the Melaka Hainanese community. 
The findings of this case study strongly indicate that the Hainanese dialect is in danger of being endangered and if steps are not taken to increase the use of the dialect, the dialect will not survive. Accordingly, there may be a need for a follow-up study on the Hainanese of Generations $\mathrm{X}$ and $\mathrm{Y}$ to confirm their level of proficiency in the dialect to assist revitalization plans for the dialect in the future.

\section{Bibliography}

Baidu Encyclopedia. (2013). 马来西亚华人. [Chinese Malaysian]. Retrieved from http://baike.baidu.com/view/1835551.htm

Carvalho, M. (2011, January 10). Villagers living in fear of erosion. The Star. Retrieved from http://thestar.com.my/news/story.asp?sec=nation\&file=/2011/1/ 10/nation/7756702

Chan, D. (2007, April 28). Last Kapitan's legacy lives on. The Star. Retrieved from http://thestar.com.my/news/story.asp?file $=/ 2007 / 4 / 28 /$ central/17551213\&sec $=$ central

Driven by poverty, rich in heritage (2012, January 9). The Star. Retrieved from http://thestar.com.my/lifestyle/story.asp?file=/2012/1/9/lifeliving/10203326

Fase et al. 1992. Maintenance and Loss of Minority Languages. Amsterdam: John Benjamins.

Federation of Hainan Association Malaysia. (2013). 海南人移民马来西亚的历史与 社会活动 [History of the Hainanese migration to Malaysia and societal activities]. Retrieved from http://www.hainannet. com.my/DataStore/MainFrameDataStore.htm

Fishman, J. (1972). Advances in the sociology of languages, Vol. 2: The Hague: Mouton.

Fishman, J. (1990). What is Reversing Language Shift (RLS) and how can it succeed? Journal of Multilingual and Multilcultural Development Vol. 11 Nos. 1 \& 2: 535.

Fu, Y. L. (2008). 海南人·海南话 [The Hainanese and the Hainanese dialect]. In Mo $\mathrm{He}$ (Ed.), 海南社会风采 [The Hainanese social style] (1st ed., pp. 96-99). Kuala Lumpur: Studio of the Hainanese Literature Studies.

Han, M. G. (2012). External and internal perceptions of the Hainanese community and identity, past and present (Bachelor's thesis). Retrieved from http://scholar bank.nus.edu/termsofuse; jsessionid=A8FD39F96CDEC595E53F3DEACE11B25 7.

Kampung Hailam in Melaka: The Hainanese Village of Melaka (2012, October 9). Guang Ming Daily. Retrieved from http://www.worldheritage.com.my/tag/guangming-daily/

Landry, R. \& Allard, R. 1994. 'Diglossia, ethnolinguistic vitality and language behaviour'. International Journal of the Sociology of Language 108: 15-42.

Liang, Q. G., \& Xu, W. Q. (2001). 丹线海南村今昔[Tanjung Kling: Past and present]. In 马六甲海南会馆千禧年纪念特刊 1869-2001 [The Melaka Hainanese Association Millennium Year Issue 1869-2001] (1st ed., pp. 151152). Melaka: The Melaka Hainanese Association.

Light, I. (1983). Cities in world perspective. New York: Macmillan.

Light, I., \& Bonacich, E. (1988). Immigrant entrepreneurs: Koreans in Los Angeles, 1965-1982. Berkeley: University of California Press. 
Sim, T. W. (2012). Why are the native languages of the Chinese Malaysians in decline? Taiwanese Language Studies, 1, 62-95. Retrieved from http://www.aca demia.edu/1520810/Why_are_the_Native_Languages_of_the_Chinese_Malaysia ns_in_Decline?

Wang, G. W. (2009). Chinese history paradigms. Asian Ethnicity, 10(3), 201-216. doi: $10.1080 / 14631360903189674$

Wang, X. M. (2010). The sociolinguistic realignment in the Chinese community in Kuala Lumpur: past, present and future. Journal of Multilingual and Multicultural Development, 31(5), 479-489. doi: 10.1080/01434632.2010. 505656

Xu, W. Z. (2005). 马六甲海南人的故事 [The story of the Malacca Hainanese]. In Mo He (Ed.), 海南社会风貌 [The Hainanese social outlook] (1st ed., pp. 34-44). Kuala Lumpur: Studio of the Hainanese Literature Studies.

海南村難逃被拆・接征用公函300老村民何去何從 [The Hainanese Village of Melaka is to be demolished: What is going to happen to the 300 elderly villagers who received the expropriation letter] (2013, April 26). Sin Chew Jit Poh. Retrieved from http://mykampung.sinchew.com.my/node/234276

马六甲海南会馆千禧年纪念特刊 1869-2001 [The Melaka Hainanese Association Millennium Year Issue 1869-2001]. (2001). Melaka: The Melaka Hainanese Association. 